\title{
Early teaching of a foreign language: what training for teachers responsible for this specialty?
}

L'apprentissage précoce d'une langue vivante: quelle formation pour les maîtres chargés de cette spécialité?

\section{Catherine Hillman-Steven}

\section{OpenEdition \\ Journals}

\section{Electronic version}

URL: http://journals.openedition.org/asp/4409

DOI: 10.4000/asp.4409

ISSN: 2108-6354

\section{Publisher}

Groupe d'étude et de recherche en anglais de spécialité

\section{Printed version}

Date of publication: 1 March 1993

Number of pages: $561-573$

ISSN: 1246-8185

\section{Electronic reference}

Catherine Hillman-Steven, «Early teaching of a foreign language: what training for teachers responsible for this specialty? », ASp [Online], 1 | 1993, Online since 05 June 2014, connection on 02 May 2019. URL : http://journals.openedition.org/asp/4409 ; DOI : 10.4000/asp.4409

This text was automatically generated on 2 May 2019.

Tous droits réservés 


\section{Early teaching of a foreign language: what training for teachers responsible for this specialty?}

L'apprentissage précoce d'une langue vivante : quelle formation pour les maîtres chargés de cette spécialité?

\section{Catherine Hillman-Steven}

1 With great sounding of trumpets 1989 saw the dawning of a new age in France: the then Minister of Education, Mr Jospin, introduced the experiment of teaching a foreign language in cours moyen (CM). The experiment was to be conducted over a period of three years before it was generally introduced in all primary schools.

2 Twenty-two per cent of children in $\mathrm{CM}$ are initiated to English, which is the main foreign language taught. Ninety per cent of the children who get the opportunity to actually begin do English. German is taught mainly in the Alsace region. There are few signs of the others. Parents are the motivating body, and the biggest voting lobby. They are obviously anxious to ensure a good place in the Euro rat-race for their children and they have been convinced, perhaps rightly so, that having them start learning English earlier is the right way to go about it.

3 The financing of the project is a ministerial headache. The S.N.I. is to be recorded as having said "Through lack of funding the Éducation nationale (EN) has passed the baby to the town councils without really admitting it".

4 The programme is very different according to the district councils. In Paris, English is offered in 81 schools and it costs the city 1,4 million FF. In many district councils in Yvelines, Noisy and St Germain-en-Laye, they have backed the English classes, sometimes sacrificing other activities like skiing or music.

5 When questioned about the extension of the project to all schools, Mr Jospin was prudent and reluctant to expand " There are 1,5 million children in CM " he said. "The cost would be exorbitant. We cannot force the councils to follow us and finance the experiment." 
14 To guarantee success we require:

- Trained teachers: skilled in the language and skilled at the teaching of same.

- Ideally five weekly lessons of 30 minutes.

- Methods adapted to children's needs.

- Continuity into the secondary school system.

- Constant teaching backing, (supposedly by the same teacher or the class's regular teacher.)

- Monitoring and assessment integrated into the teaching.

In Normandy reality is as follows:

- $60 \%$ of the C.M benefit from the experiment.

- The choice of teachers is mentioned above.

- Two 45 min. sessions are conducted weekly.

Methods are decided upon what the town council can afford, and according to what the teacher imposes. If any, Stepping Stones, Flash, Muzzy in Gondoland, Early Bird, there are many. Following a method is very strongly advised by the co-ordinators, as a progress guide for both teachers and pupils, especially for pre- $6^{\mathrm{e}}$ pupils, but teachers will do as they will. 
Assessment of the pupils' work and progress remains a very delicate issue, as does assessment of the teachers' work. All attempts at assessment have proved unsatisfactory. However, most of the teachers who meet these same children in secondary are almost unanimous in their opinion that the children have an edge over those who have never done any English at all.

We are inclined to believe that the experience would be more beneficial to those who had already been involved in the project if they could be grouped homogenously. This was the big problem in the U.K. in the 1970's when they developed French in primary experiment. According to Clare Burstall's report (1974), when there was no regrouping, the benefits were soon shed through boredom at being too far ahead, the fastidious beginners "donkey work", or lack of skilful management of these early starters in the classroom. To avoid this obvious pitfall, in some parts of France and particularly in the college Boris Vian in Mezidon where we work, all the rural primaries of the area have been involved in the experiment and will send their children to this same college and therefore no pupil will begin English at zero point. This scheme itself requires much engineering and coordination by the Head and the staff involved. The results will be followed through by ourselves as from September 1992.

So the results of the experiment have given rise to the widest range of opinions. It would seem as always, and this is no surprise to anyone in the academic world that it all depends on who is performing and how, and also with whom. Must we plunge into the ancient clichés of the socio-economically over or under privileged? The enlightened or the culturally impoverished or over-endowed? I think not.

No matter what we do in CM2 we feel the results will be the same as they always have been. After six or seven years of learning English in secondary schools $60 \%$ of our children will close up like clams when questioned spontaneously in English, outside of a classroom situation, and probably as many inside. Seventy-five per cent will understand literally nothing of $\mathrm{BBC}$ broadcast on a first hearing. And this in spite of constant use of machines of all shapes and sizes and varieties which deliver authentic utterances from native speakers. Teachers battle with the Conseil d'Administration to have the best new machines on the market, including super video and T.V sets without forgetting satellite dishes... Language labs the prices of houses are set up to ensure fluency and linguistic skills in the bigger and senior houses of learning. This is all to no avail.

By the time the pupils who are the top $6 \%$ of our nation's young, the cream of the crop, actually sit the competitive exams, they are so brainwashed into examination techniques, that they have lost the level of fluency they have taken pains to acquire up until the terminal class. The teacher in the prep schools, who has reached the pinnacle of his secondary school career finds himself stuck with the job of using any possible technique which will enable the cramming system to work. It is in contradiction to what the code of a living environment is. In lycée, anything goes, in Prepa nothing goes. The students are weighed down by mental topheaviness quite dislocated with any other human experience. The approach to English is the same as to that of a "dead" language.

21 In the name of speaking English for Europe we are lost in a quagmire of machines and caught up in a hysterical and massive spending spree. Everybody has been jumping on the bandwagon.

22 At Expolangues in February 1992, more than half the space was occupied by stands selling courses right left and centre with watertight guarantees of fluency within a week, etc. 
English is big business, but we have got it all wrong or at least the wrong end of the stick. The lonely traveller we are concerned with is the child who starts on the long road to adulthood, not the future yuppy who's born with a telephone stuck to his ear. What we are offering him today is the monstrosity of technology and too late to do him any good.

Technology should be no more or no less than a teaching aid and in no way replace the teacher. As far as English teaching is concerned let us consider the present situation. From baby-hood to nursery school we teach the child how to think (hopefully). Then we teach him how to learn. But his skills are of no use in language learning.

In the 70 's we used to have them listen to tapes of rigmarole over again and mine until we were blue in the face to express the meaning of what was being said. The bright ones understood immediately and the slower, never. Generation of children were lost. We have let story telling and explication take a back seat to "visual literalism".

Most children today think Walt Disney wrote Peter Pan, Robin Hood and the Sleeping Beauty, Mel Gibson is Hamlet and dying is what happens on T.V, etc. That is visual literalism. "The story is subordinated to spectacle, drama to design, and our own fantasies usurped to archaeological realism."

The emotional effects matter less than the special effects, and the children's imaginations are so bound by T.V baseball and fun park images that they will only respond to the known...

\section{We live in an age where the eye dominates the ear.}

Imagination and exploration are well nigh redundant.

Unless you are a superb actor and you have a class of dumb angels you can have in seconds the chaotic situation of the kids yelling at you or each other in French. A swift sketch on the board or a frown will give rise to the most inevitably uncouth but comprehensive interpretations.

They are not prepared to listen to the news when they can see the riots in L.A. on T.V. It's much more spectacular. Video games are held responsible for classroom chaos, said one doctor on B.B.C. Radio 4 programme broadcast in FEB 92. Thanks to those vicious engines wielding death or success at the press of a button they have immediate gratification or despair at their fingertips. Equally perturbing, you have the triteness of the morals of Miss Goody Two Shoes and the sickening soap opera sentimentality of the happy nuclear family which has no place in reality and is paramount in child oriented cinema and T.V.

Maurice Sendak of Where the Wild Things Are fame, one of American's most esteemed illustrators was strongly criticised for his cruelty towards children in his stories. Max gets sent to bed without supper for being naughty. In Higglety Pigglety Pop, the baby is abandoned by his parents; but he believes that his story children master their terrors and emerge exalted. Sendak is caustic about what visual literalism does to children and holds adults responsible. On the theme of the recent great box office hit Home Alone. (A child is left behind at home while his parents go on a Christmas skiing trip. Far fetched enough, but the place is attacked and robbed by murderous thieves and the boy ends up by killing them all). It's an updated Babes in the Wood or Hansel and Gretel. He says: "It was crude and vulgar and disgusting, but not surprising in a culture which takes children to watch Rambo films where the audience laughs as heads are shot off..."

31 If those films are popular with children it is because kids "are really congenital garbage cans. They just eat everything. It is up to adults to guide their taste." Our children are not 
equipped mentally to wait, guess or expect or even listen, never mind cope with a new code which a foreign language is to them.

We have to reach the children far sooner than CM2 age 10. 
We believe that if the basic universal elements of the language are introduced at this very early age we will reach a higher point of understanding of our neighbour. This would be a very solid foundation for our teachers to work on. They are the ideal initiators because they occupy that privileged position second only to the mother's.

If the future body of young primary teachers is brought to full awareness while still at college, and well prepared to take on the initiation, the country will arrive at the semi bilingual stage the Swedes have managed to reach.

5 After a ten year experiment conducted in Sweden, L.S.E Holmstrand (1982), in his final report, formally rejected the undying myth that surrounds early language teaching, namely that it was bad for their reading and the learning of their mother tongue and secondly, which is a debatable point that they were better at language learning at that age than at many other skills.

But what we want to achieve along with the linguistic skills is the rightful position of a language that is not only the vehicle of a few privileged businessmen negotiating with the Japanese. Without the teaching of its code for beauty as well as for negotiating no matter how naive and romantic that sounds we will make our language redundant. Of course what good does poetry and literature do, one hears. We are victims of visual literalism remember. We have to fight its enormous tidal wave. We have to begin now. Danger lights are flashing. English at five is not utopia, it is simply a question of new organisation and the pooling of enthusiasm and talent.

It's better to light one candle than curse the darkness. (Shakespeare, Two Gentlemen of Verona Act $3 \mathrm{Sc} .2)$

We received a business school prospectus encouraging the cream of our nation to apply to this school:

À l'aube de l'an 2000, la politique et le droit sont soumis à la loi de l'économie. Les concepts philosophiques qui dominaient hier ont laissé place à l'hégémonie des échanges commerciaux. Les penseurs qui exercent une influence sur la société se trouvent désormais à la tête des entreprises. Aujourd'hui, l'ordre mondial n'est plus tout à fait utopique; les régimes politiques totalitaires sont de moins en moins nombreux; l'économie de marché a prouvé sa supériorité sur les autres formes d'échanges.

48 The message is clear. This is the new business revolution, ushering in a new totalitarian regime. So is our language to become simply a vehicle stripped of its beauty and expression and its original purpose, communication between men. Are we to take this lying down?

Are we to be bulldozered into encouraging our students to believe that the only hallmark of success is reaching the top in the business world? Are they to be bamboozled into believing that nothing else is worth doing in this god-forsaken world of progress? Is there to be only one set of values acceptable to ourselves and our children? 


\section{BIBLIOGRAPHY}

Bailly, Danielle \& Christiane Luc. 1992. Approche d'une langue étrangère à l'école. Volume 2 Étude psycholinguistique et aspects didactiques. Paris: I.N.R.P.

Bréant, P. (dir.). 1990. “L'enseignement précoce des langues vivantes”. Centre de formation des inspecteurs départementaux.

Brewster, Jean \& Gail Ellis. 1990. The Storytelling Handbook. London: Penguin.

Burstall, Clare. 1975. "Primary French in the Balance”. Educational Research 17 1975, 193-198.

Ellis, Gail \& Daniel Girard. 1992. Guide de l'anglais précoce: Bridging the gap. Paris: Penguin.

Favard, Jean. 1990. Évaluation de l'enseignement précoce des langues vivantes “1989-1990”. Rapport Inspection générale.

Holmstrand L. S. E. 1982. English in the Elementary School. Stockohlm-Uppsala: Almqvist and Wiksell International.

Journal of the British Institute in Paris 11, Spring 1991. Special issue "Language teaching in the 1990 's.

Sendak, Maurice. 1963. Where the Wild Things Are. New York: Harper and Row Publishers Scholastic Book Services.

Tomatis Alfred. 1963. Le langage et l'oreille. Paris: Seuil, Coll. Points.

\section{Newspaper and magazine articles}

Alderson, Brian. 1992. “Are you all sitting uncomfortably?”. The Times Sat. May 21992.

Billington, Michael. 1992. "Hooked on a designer's dream”. The Guardian Weekly May 3rd.

Heron, E. 1991. “Le loup holds no fears for 4 year olds"”. Times Educational Supplement 38961 March 1991.

Le Monde 6 sept. 1989. "Campus, l'anglais par ordinateur".

Le Monde 13 fév. 1992. "Éducation : le poète et le laser".

Le Monde 24 avril 1992. "Maintenant la rénovation de la classe de seconde".

L'Express. 1991 déc. “Jospin et les langues".

Sharpe, K. 1989. “Smothered tongue”. Times Educational Supplement 38052 June 1989.

\section{NOTES}

1. CRITT (Centre d'innovation et de transfert de technologie), Université de Rennes.

2. Cf. ELM: Espaces langues multimédia à séquences individualisées, alternatives aux laboratoires de langues. 


\section{AUTHOR}

\section{CATHERINE HILLMAN-STEVEN}

Institut d'Administration des Entreprises (IAE) de Basse-Normandie, Université de Caen. 